\title{
Draft notes from a "Consultation Meeting on the Elimination of Gender Based Violence in Afghanistan" \\ Hosted by UNIFEM Thursday, April 29, 2004
}

Please see attached sheet for the list of participants.

Purpose - To purpose of the meeting was to begin a dialogue on issues related to gender based violence in Afghanistan. UNIFEM presented some of its preliminary ideas on what steps it could take on this issue. This included research and data collection; the legal framework; the media and public awareness; advocacy on security sector reform. A 4-page concept note was distributed in English and Dari. Representatives from government, NGO's and the donor community attended this meeting which was moderated by Carolyn McCool, A/Programme Director, UNIFEM Afghanistan. The meeting was attended by H.E Dr. Sarabi, the Minister of Women's Affairs.

Main discussion points - The discussion points and comments made by participants included;

Gender based violence in Afghanistan is highly complex and sensitive issue that requires a long term, Afghan led solution. It is important that it not been seen as foreign led and anti Afghan culture. There could be a back lash if it is not done in a very sensitive way; a way that is embedded in the culture and Islamic religion.

A stronger response to issues related to gender based violence is long overdue. There is already a strong demand from civil society, government and donors. The scope of this issue requires multi-agency or multi-institution and multi-donor approach.

Research, advocacy and programmes are all needed, but first and foremost steps must be taken to develop a rule of law society. Women and men do not know their rights and customary laws prevail for most Afghan people. Massive awareness rising is needed so men and women understand their rights and this must be done in a way that is respectful of the culture and religion. There is a need to educate women and this takes time. Tribal shuras need to understand these issue as they the ones who know the context and raise awareness among other men.

AIHRC and others reported some alarming trends - self immolation (or burning) is a big problem in Herat and all over Afghanistan. Suicide, selling and trafficking of women are also reported to be increasing. In the last few weeks four girls were kidnapped and there have been several deaths of women in Jalalabad. It was also reported to the meeting that women working for NGOs and girls going to school are being threatened and told to "adopt an appropriate manner". Women participating in the National Solidarity Programme (NSP) councils are also reported to be targets. It is unclear if the perpetrators are "anti- women" or in opposition to the government and the NSP. Immediate action needs to be taken on these urgent issues while a nationally owned approach is developed and implemented.

It would be ill-advised to take strong action on this issue before the election - otherwise people will think it's a plan from the foreigners. The Ministry of Women's Affairs has discussed this issue and has done some planning. There needs to be a national government plan that includes MoJ, MoI and MoD.

After the elections there will be a parliament where we can expect $25 \%$ of parliamentarians to be women. Issues of gender based violence could be an issue taken up at the parliamentary level. This approach would ensure that it is Afghan led. More attention needs to be given on ways to support women to stand for election. More thought also needs to be given on ways to support female parliamentarians so they can be effective representatives of the people. It was noted that women are not being appointed in high
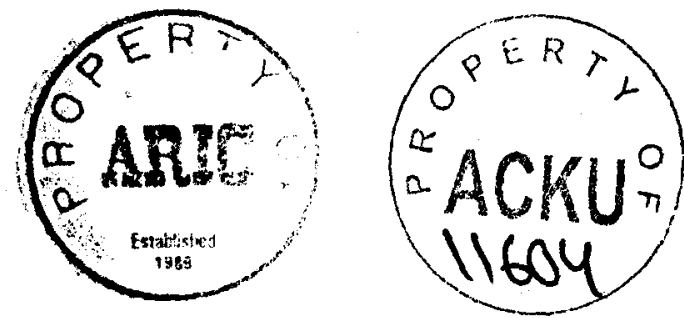
positions in the government and often systematically excluded from important meetings. It was argued that this in itself is a form of violence.

There is a need for more shelters and services for the victims of domestic violence. Lives are being lost and more needs to be done to prevent further loss of life. Some women and men think it that shelters are inappropriate and there is a concern that shelters will cause social disarray. It was suggested that shelters should be affiliated to the government.

Participants welcomed UNIFEM's suggestion that advocacy is needed around security reform and that too little attention is given to women and gender issues in DDR, development of the ANA and police reform. One participant said; "if we can't finish warlordism all these plans will fail."

Any new initiatives, such as a National Media Campaign, must learn from the experiences from other Islamic countries and build on existing initiatives in country.

There is a need for capacity building in the international community on Islam.

\section{Existing resources and planned work}

The European Commission outlined its tentative commitment to support a 4million Euro Domestic Violence project. Approximately 800,000 Euros will go towards a domestic violence survey; 2.8 million for awareness raising activities and aid to victims such as medical aid, psycho social support and; 400,000 Euro to support the burn unit of the Herat hospital. The European Commission agreed to share its proposal when it is finalized.

AIHRC is publishing a book on violence against women in dari and pashtu. They already have a book on Self Immolation of women based Herat and all provinces.

Canada, through their support to the Ministry of Interior and the police, will look into gender sensitizing of the police force as a means to address these issues. A Canadian Justice mission is coming soon and they will meet with the Minister about addressing these issues.

NOVIB/OXFAM recently started a mapping exercise to find out what organizations are working on gender based violence issues what approaches they are using, whether the approaches used are adequate to address the issue etc. Through this exercise, NOVIB are also looking into studies done in Afghanistan on gender based violence.

Medica Mondial is currently conducting research of female suicide in Kabul.

\section{How to carry this ahead?}

It was agreed that it is important to generate more dialogue on these issues and there needs to be coordination from an early stage. It was re-emphasized that all approaches dealing with violence against women must be Afghan led. The next meeting should have more Afghan participants. The Minister of Education and Higher Education, Ministry of Defense, Interior, Justice and the Attorney General office all need to be involved. There will be another "discussion forum" in 2 weeks time i.e.:

\section{Wednesday May 12 in the UNDP conference room from 1:30pm-3:00pm (to be confirmed).}

Marzia Basel from UNIFEM will put together a participants list and share with the Minister and Momina from the AIHRC. 


\section{List of Attendees}

"Consultation Meeting on the Elimination of Gender Based Violence in Afghanistan"

UNDP Conference Room, Thursday, April 29, 2004

\begin{tabular}{|c|c|c|c|c|c|}
\hline & Name & Position & Organization & Telephone \# & Email \\
\hline 1 & H.E Dr. Habiba Sarabi & Minister & Ministry of Women's Affairs & & \\
\hline 2 & Momina Yari & Programme Manager & AIHRC & 079341456 & Myari8@hotmail.com \\
\hline 3 & Sadiga Basiri & Advocacy Manager & Afghan Women's Network & & \\
\hline 4 & Adela Ruz & Political Affairs Assistant & UNAMA & 070229244 & Raz1@un.org \\
\hline 5 & Serena Di Matteo & Consultant & Italian Embassy & 070296869 & Serena.dimatteo@esteroi.it \\
\hline 6 & Katrin Leo & Attache & Embassy of Denmark & 070280339 & Kabul@umweb.dk \\
\hline 7 & Ginette Barton & Gender Programme Officer & IOM & 070275875 & gbaerten@iomkbaul.net \\
\hline 8 & Meloney Lindburg & Assistant Representative & The Asia Foundation & 079340207 & mlindberg@afg.asiafound.org \\
\hline 9 & Homira Nassery & Advisor & MRRD/UNDP & 070222118 & hnassery@worldbank.org \\
\hline 10 & Tamim Asey & Development Officer & Embassy of Canada/CIDA & 079304335 & canadakabulcida@yahoo.com \\
\hline 11 & Lilly Saray & Programme Assistant & UNDP & 070308317 & Lilly.seray@undp.org \\
\hline 12 & Ed Burke & Senior Programme Specialist & UNESCO & 070277485 & Ed.burke@undp.org \\
\hline 13 & Ann Jones & Researcher & Medica Mondiale & 070238048 & Anninkabul@yahoo.com \\
\hline 14 & Tahmina Baloch & Consultant & NOVIB/Oxfam & 079342877 & Tahmina_Baloch@hotmail.com \\
\hline 15 & Shaheer Shahriar & Political and Press Assistant & British Embassy & 070274772 & Shaheer.shahriar@fco.gov.uk \\
\hline 16 & Elizabeth Rousset & Deputy Head of Operations & $\mathrm{EC}$ & & \\
\hline 17 & Semin Qarui & Programme Officer & GTZ & 070224810 & seminhasmi@hotmail.com \\
\hline 18 & Heike Markert & Programme Advisor & GTZ & 070283592 & Markert.h@web.de \\
\hline 19 & Simone Troller & Human Rights Officer & UNAMA & 079565579 & troller@un.org \\
\hline 20 & Eng Naeem Asghari & Capacity Building Manager & $\mathrm{AWN}$ & 070241436 & \\
\hline 21 & Marzia Basel & Gender Justice Officer & UNIFEM & 070210076 & Marzia.basel@undp.org \\
\hline 22 & Helen Brereton & Programme Specialist & UNIFEM & 070278309 & Helen.brereton@undp.org \\
\hline
\end{tabular}

Moderated by - Carolyn McCool, A/Programme Director, UNIFEM

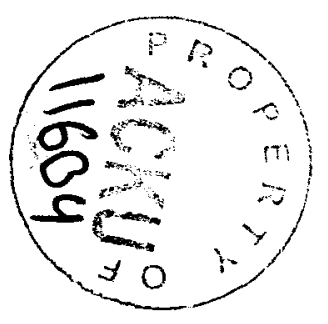




\section{UNITED NATIONS DEVELOPMENT FUND FOR WOMEN ATTENDENCE SHEET OF GENDER BASED VIOLENCE IN AFGHANISTAN DISCUSSION}

DATE: MAY 12TH 2004

\begin{tabular}{|c|c|c|c|c|c|}
\hline S\# & Name & Position & Organization & Tele. No. & Email Address \\
\hline 1 & A. Ghafrar Orfany & Chief of crime & Attorney General Office & $\begin{array}{l}079-4285 \\
50\end{array}$ & \\
\hline 2 & Noorani & S.Prog. Assistant & IOM & $\begin{array}{l}079-3441 \\
41\end{array}$ & \\
\hline 3 & M.Khalil & Prog. Assistant & IOM & $\begin{array}{l}0793206041 \\
070247310\end{array}$ & \\
\hline 4 & Shaheer Shahryar & Political and press assistant & British Embassy & $\begin{array}{l}070-2747 \\
72\end{array}$ & shaheer.shahriar@fco.gov.uk \\
\hline 5 & Tahmina Balooch & Consultant & NOVIB/OXFAM & $\begin{array}{l}079-3428 \\
77\end{array}$ & tahmina baloch@hotmail.com \\
\hline 6 & Malika Sahadat & Deputy Director & SRSO & $\begin{array}{l}079-3098 \\
94\end{array}$ & malikasahadat@hotmail.com \\
\hline 7 & Woranga Safi & Deputy Secondary Edu. Dept. & MOE & $\begin{array}{l}079-0112 \\
28\end{array}$ & \\
\hline 8 & Tamim Asey & Development officer & Embassy of Canada CIDA & $\begin{array}{l}079-3043 \\
35\end{array}$ & canadakabulcida1@yahoo.com \\
\hline 9 & Serena Di Matteo & Consultant & Embassy of Italy & $\begin{array}{l}070-2968 \\
69\end{array}$ & serenadimatteo3@hotmail.com \\
\hline 10 & Freshta Karimi & Legal Project Coordinator & Medical Mondiale & $\begin{array}{l}070-2119 \\
33\end{array}$ & freshta285@hotmail.com \\
\hline 11 & Massoda Nawabi & LAF.Prog. Prison Project.co & Medical Mondiale & $\begin{array}{l}070-2397 \\
65\end{array}$ & masoodanawab@hotmail.com \\
\hline 12 & Aziza Adalatkhwah & LAF Trainer/D.L & Medical Mondiale & $\begin{array}{l}070-2480 \\
20\end{array}$ & \\
\hline 13 & Zohra Rasekh & Director, office of women's affairs & MoFA & $\begin{array}{l}070-2987 \\
67\end{array}$ & zrasekh@aol.com \\
\hline 14 & Momena Yari & Program Manager & AlHRC & $\begin{array}{l}079-3414 \\
56\end{array}$ & myari8@hotmail.com \\
\hline 15 & Simon Treller & Human Rights Office & UNAMA & $\begin{array}{l}079-5655 \\
79\end{array}$ & troller@un.org \\
\hline 16 & Mr.Mohagqeg & Research consultant & MoWA & $\begin{array}{l}070-2550 \\
45\end{array}$ & mohaghegh02@yahoo.co.uk \\
\hline 17 & Adeln Raz & Political affairs assistant & UNAMA & $\begin{array}{l}070-2292 \\
44\end{array}$ & raz1@un.org \\
\hline 18 & Melony Lindberg & Assistant Representative & The Asia Foundation & $079-3402$ & mlindberg@ag.asiafound.org \\
\hline
\end{tabular}




\begin{tabular}{|c|c|c|c|c|c|}
\hline & & & & 07 & \\
\hline 19 & Ed Burke & S.Prog. Specialist & UNESCO & $\begin{array}{l}070-2774 \\
85\end{array}$ & ed.burke@undp.org \\
\hline 20 & Saad Hamid & Gender and Justice Advisor & UNIFEM & $\begin{array}{l}070-2258 \\
49\end{array}$ & saad.hamid@undp.org \\
\hline 21 & Sadiga Basiri & Advocacy Manager & AWN & $\begin{array}{l}070-2865 \\
98\end{array}$ & awnkabul@hotmail.com \\
\hline 22 & Palwasha Hassan & Coordinator & Rights and Democracy & $\begin{array}{l}070-2834 \\
40\end{array}$ & palwasha@ceretechs.com \\
\hline 23 & Dr.Zabunnesa & National Program Officer & UNFPA & $\begin{array}{l}070-2762 \\
59\end{array}$ & zibulnessa@unfpa.org \\
\hline 24 & Helen Brereton & Program & UNIFEM & $\begin{array}{l}070-2783 \\
09\end{array}$ & helen.brereton@undp.org \\
\hline 25 & Marzia Basel & Gender and Justice Officer & UNIFEM & $\begin{array}{l}070-2100 \\
70\end{array}$ & mazia.basel@undp.org \\
\hline 26 & Suraya Paikan & Director & AWLPA & $\begin{array}{l}070-2101 \\
22\end{array}$ & awlpa@yahoo.com \\
\hline 27 & General Aziza Nazari & Deputy Human rights office & Mol & $\begin{array}{l}070-2065 \\
93\end{array}$ & \\
\hline 28 & Lilly Seray & Prog. Assistant & UNDP & $\begin{array}{l}079-3063 \\
17\end{array}$ & lilly.serai@undp.org \\
\hline 29 & Adraina Zareluqui & Gender and Legal Advisor & CDDP/MMD & $\begin{array}{l}079-3080 \\
65\end{array}$ & adrianez@unopsmail.org \\
\hline 30 & Ann Jones & VAW research consultant & Medical Mondiale & $\begin{array}{l}070-2380 \\
48\end{array}$ & anninkabul@yahoo.com \\
\hline 31 & Hangama Anwari & & Women \& Children Rights Research & & hangam anwari@yahoo.com \\
\hline 32 & Katrin Leo & & Embassy of Denmark & $\begin{array}{l}070-2803 \\
39\end{array}$ & kabul@umweb.dk \\
\hline
\end{tabular}

